Микитюк, Оксана. «Мовно-політичний світогляд Лесі Українки (за творами Дмитра Донцова)». Лінгвостилістичні студї, вип. 14, 2021, с. 89-99.

Mykytyuk, Oksana. "Linguistic and Political Worldview of Lesia Ukrainka (a Case Study of the Works by Dmytro Dontsov)". Linguostylistic Studies, iss. 14, 2021, pp. 89-99.

Удк 821'272.161.2(092)Українка

https://doi.org/10.29038/2413-0923-2021-14-89-99

\title{
МОВНО-ПОЛІТИЧНИЙ СВІТОГЛЯД ЛЕСІ УКРАЇНКИ (ЗА ТВОРАМИ ДМИТРА ДОНЦОВА)
}

\author{
Оксана Микитюк \\ Національний університет «Львівська політехніка», \\ Львів, Україна
}

У статті проаналізовано мовно-політичний світогляд Лесі Українки. Доведено, що персономен Леся Украӥнка є стилістично вмотивований та ідеологічно підкріплений націєцентричною ідеологією Д. Донцова. 3'ясовано, що програма боротьби, розуміння категорії свій, осутнення біблійних постулатів та ідея ствердження сили духу - усі базові державницькі засади є спільними для творів Лесі Українки та Д. Донцова.

Ключові слова: персономен, омовлення боротьби, категорія свій, біблійні елементи.

\section{LINGUISTIC AND POLITICAL WORLDVIEW OF LESIA UKRAINKA (A CASE STUDY OF THE WORKS BY DMYTRO DONTSOV)}

\author{
Oksana Mykytyuk \\ Lviv Polytechnic National University, Lviv, Ukraine
}

The article elucidates a linguistic, political, and ideological interpretation of Lesya Ukrainka's creative work against the background of the socio-political picture of that time. The case study material of the article is the works of D. Dontsov, presented in a 10 -volume edition and his separate books.

The research has provided the creation of a linguistic and political portrait of Lesya Ukrainka, which has a pivotal significance for assessing D. Dontsov's views. The has proved that the thinker admired the encyclopedic writing of Lesya Ukrainka, emphasized the ideological content of her works, which formed national dignity, generated the revolting spirit, and promoted the desire to commit great deeds. D. Dontsov, like I. Franko, understood the pathos of the style of the poet, who was the first after T. Shevchenko to claim that Ukrainians have their own guiding force, their own national idea, which is unique by its nature.

The embodiment of the struggle for the human soul in the language is a common and principal theme in the works of Lesya Ukrainka and D. Dontsov. The thinker uses the personomen Lesya Ukrainka to convey a certain event and to strengthen his opinion. An important research finding is a statement that the poet-prophetess adheres to her Ukrainian dream in ancient images to show that faith, struggle, and victory were already a sign of

(c) Микитюк О., Волинський національний університет імені Лесі Українки, 2021.

Це стаття відкритого доступу на умовах СC BY-NC 4.0 
ancient heroic times. D. Dontsov also analyzes the defeat of the national liberation struggle, which was not an obstacle to the desire of Ukrainians for independence.

The study argues that the worldview of Lesya Ukrainka is a model of invincibility for D. Dontsov. They both base their views on the concepts of their own people, own land, own way, own character, own truth.

Stylistically colored are the biblical elements in the works of D. Dontsov, being enhanced by the personomen Lesya Ukrainka. Numerous examples illustrate the thinker's statement that the Scriptures know only the words "Yes" and "No" and those who do not know how to use them properly are people without faith and without love. The world history will throw them in the trash - a halfway is extremely dangerous.

Characterizing Lesya Ukrainka in the aspect of linguo-personology is important for showing the political situation of the country and reproducing the national ideas of that time .

Key words: personology (personomen), embodiment of the struggle in the language, category of 'own', biblical elements.

Вступ. Понадчасовою $є$ цитата Ю. Щербака про публіцистику як «оголений нерв літератури, наймобільніший ï жанр», як «кардіограму суспільних настроїв» (Літературна Україна. 15 грудня 1988). Цю знакову метафору «оголений нерв» нині відтворено в назві роману української письменниці С. Талан про Майдан і російсько-українську війну на Донбасі. Не зайвим $є$ наголосити, що «оголеним нервом» $є$ твори Д. Донцова, які було викорінено з українського простору, що спричинило глибоку лакуну в жанрі правдивої, викривальної та безкомпромісової публіцистики.

Міжпредметнісний розгляд мовного портрета Д. Донцова має своїм опертям дані історії (Дашкевич; Шліхта), літератури (Баган, Поміж; Денисюк; Забужко; Маланюк; Міщенко), політології (Квіт; Шліхта; Erlacher), філософії (Чугуєнко), соціальної комунікації (Супрун). Отож в українському просторі Д. Донцов відомий передусім як політичний діяч та мислитель, тому доречно загострити увагу на мовленнєвій палітрі його текстів. Стилістичні ресурси праць публіциста дивовижні: це численні антитези, дефініції, метафори, перифрази, тавтології та багатющі ряди синонімів. Нас цікавить Донцовський стиль щодо наявности персономена, себто використання назви реальної постаті, проаналізованої крізь світосприйняття автора твору.

Портретування Лесі Українки є предметом зацікавлень філологічної спільноти, зокрема, на тлі екстралінгвальних чинників їі мовну самобутність охарактеризували Л. Мацько, І. Фаріон (Мацько; Фаріон). Неймовірно цікаві розвідки на основі епістолярію та зібрання творів Лесі Українки здійснила С. Богдан (Богдан, Еnістолярний; Богдан, «Мені»). Західноукраїнські мовні елементи у творчості письменниці проаналізувала Л. Трач (Трач). Різноаспектно висвітлено креативні коди, мовотворчість, перекладацьку діяльність у збірникові на пошану 150-річчя від дня народження Лариси Петрівни Квітки-Косач (Ідеологиня). Варто зауважити, що до творчости Лесі Українки звертався представник націоналістичного напряму Р.Бжеський, роботи якого є предметом розгляду М. Гладкович (Гладкович). 
Мета дослідження: проаналізувати мовно-політичне та світоглядове розуміння творчости Лесі Українки, яке блискуче оприявнив Д. Донцов. Поставлена мета передбачає розгляд таких завдань:

- показати персономен Леся Украӥнка як ідеологічно стилетвірний елемент публіцистики ідеолога українського націоналізму;

- охарактеризувати політичну основу творів «поетки-пророчиці»;

- довести, що програма боротьби є спільною для Лесі Українки та Д. Донцова;

- виокремити категорію свій у поетки та мислителя;

- дослідити біблійні елементи у творчості Лесі Українки;

- унаочнити думки Д.Донцова про літературну силу духу Лесі Українки.

Матеріал і методи дослідження. Джерелами роботи слугували твори Д.Донцова, подані у 10-томовому виданні (Донцов, Вибрані), та окремі книжки: «Дух нашої давнини» (Донцов, Дух), «Націоналізм» (Донцов, Націоналізм), «Хрестом і мечем» (Донцов, Хрестом).

У роботі використано загальнонаукові та лінгвостилістичні методи, що уможливили аналіз матеріалу. Серед загальнонаукових основними $\epsilon$ такі: метод спостереження, за допомогою якого аргументовано доцільність вибору певного тексту; метод емпіричного аналізу, позаяк зібрано покласифіковано та узагальнено джерельну базу, та метод міжпредметнісного аналізу, що грунтований на залученні даних різних наук, зокрема, політології, літератури, філософії тощо.

Щодо лінгвостилістичних методів, то послуговуємося методом антропоцентричного аналізу, який застосовано для трактування текстів крізь призму світоглядових маркерів Д. Донцова; методом лінгвістичної інтерпретації, який відтворює суть публіцистичного тексту на основі вивчення мовних одиниць певного рівня; інформаційно-смисловим методом, який уможливлює пояснення тексту з погляду ідеологічної та суспільно-політичної позиції автора; методом контекстуального аналізу, що відтворює контекст як цілісну структуру 3 певним ідеологічним підкладом.

Результати дослідження та дискусія. Чільним штрихом для розширення царини лінгвоперсонології $є$ опис постаті на тлі суспільнополітичної характеристики певного часу. Відтак мовний портрет Лесі Українки має стрижневе значення для оцінки поглядів Д. Донцова. Твори ідеолога українського націоналізму зцементували світоглядові позиції українців, а про захоплення постаттю «Бурі і натиску» свідчать такі слова Д. Донцова «Поезія Лесі Українки була енциклопедією наших часів, як твори Монтеня або Рабле були енциклопедією XVI віку» (Донцов, Вибрані 8: 35). Фундаментальною є ідея мислителя про слово як молот в Лесі Українки, яким вона «гатила в недовірків. А з инших - кувала нову психіку великого народу. Тверду і непокірну» (Донцов, Вибрані 8: 351). Ця цитата 
формує бачення позиції письменниці, іiї оцінку дійсности, яка випереджала час, не залежала від думки оточення. Творець покоління УПА у своїй публіцистиці виразно випише сутнісні ознаки стилю та характеру Лесі Українки - порив та бунт.

Аргументаційну базу Д. Донцова зміцнює введений у твори персономен Леся Українка, який висвітлено для окреслення: 1) політичної ситуації 2) шляхів боротьби 3) категорії свій, 4) біблійних мотивів 5) сили духу.

\section{1. Національно-політичний ідеал творів Лесі Українки}

Соціолінгвальна ситуація, коли Україна була роздерта межи двома імперіями - Австро-Угорщиною та царською Росією, стала основою політичної маніфестації творів Лесі Українки. Очевидним $є$ факт, що національне виховання Леся отримала від матері, Олени Пчілки, працьовитість якої засвідчує не лише ії псевдонім, а й участь у культурнополітичному житті краю. Крім того, позитивний вплив зробило й оточення, яке формувало ідеали малої Лесі. Національну свідомість письменниці впізнає Д. Донцов: «Який відмінний світогляд від пануючого серед тогочасної нашої, не лиш соціялістичної, інтелігенції... Сей світогляд був, зрештою, наскрізь консеквентний» (Донцов, Вибрані 8: 32). Тож український стрижень, власні догмати віри, неперервна боротьба - усе це було ідеалом Лесі Українки, який вона втілила у своїх творах.

Доленосною для розуміння політичного обширу письменниці стала розвідка I. Франка, бо «від часу Шевченкового “Поховайте та вставайте, кайдани порвіте” Україна не чула такого сильного, гарячого та поетичного слова» (Франко 265-6). Гідно оцінив її стиль Каменяр українського духу, бо «Леся Українка не силкується на Шевченків пафос, не пережовує його термінології; у неї є свій пафос, своє власне слово.... Поетичне слово доспіло і сипеться, мов золота пшениця» (Франко 266). Аналогічно стверджує Д.Донцов, оскільки Леся Українка «вперше по Шевченку показала, що українська стихія потрапить сама з себе, з власних сил, із непозичених в инших ідеалів видобути той великий патос, створити ту творчу легенду, ту розгонову силу, яких ії заблукані попередники надаремне шукали в чужих національних ідеях або в інтернаціоналізмі», перетворюючись таким чином в «роздвоєні душі із спаралізованим почуванням і зі зламаними думками» (Донцов, Вибрані 8: 35).

Отже, «для лінгвоперсонології істотними постають і світогляд, i безпосередня картина світу» (Загнітко 132), яку Д. Донцов відтворює через видатну постать Лесі Українки.

\section{Українки}

2. Шляхи боротьби - це спільна тема для Д.Донцова та Лесі

Есей «Поетка українського Рисорджименто», який Д. Донцов опублікував у «Літературно-науковому вістнику», відтворив ідеологію Лесі Українки, яка була визначальною для мислителя. У творі подано «головну концепцію переформатування нації: назад до Середньовіччя, до основ ірраціонального, героїчного, релігійного» (Баган, Ідеологія 10). 
Омовлення боротьби має яскраву специфіку в творах Лесі Українки. Своєю сміливістю висловлювань, твердістю характеру вона викликала щонайменше подив в оточення та пієтет у великого публіциста. Ї̈̈ завданням було, як і Д.Донцова, пробудити до чину та відтворити дух лицарства. Мислитель переконує, що боротьба йде за душу людини, тому констатує: «Боротьба з дияволом, як писала Леся Українка, перейшла на землю з неба, вона загострилася особливо в наш час» (Донцов, Вибрані 9: 34).

Мотиваційною основою використання персономена Леся Украӥнка в Д. Донцова $€$ не лише відреагувати на певну подію, а дати їй опертя, підкріплене часом. Відтак і мислитель, і Леся Українка обирають реальності минулого для характеристики сучасного. Описані події в поетки стосуються далеких часів, коли героїчне минуле було в силі. Д. Донцов відчитав у ії текстах ті ідеї, які стали чільними в ідеології націоналізму. Наприклад, в «Оргії» Леся Українка показує, як сильний «народ Ахілів і Демостенів, який із погордою дивився на чужинців як на “варварів", зробився “ахайською галайстрою” без сорому і чести», бо «щось відлетіло з душі тих людей, що робило їх народом» (Донцов, Вибрані 4: 41). Мислитель (за творами письменниці) констатує, що таким народом, який вважав колись себе найсильнішим, найвідважнішим, найрозумнішим, який любив свободу, були українці. Д. Донцов озвучує позицію Лесі Українки через образ переслідуваного християнина, чин якого став тим незламним духом, яким християнство перемогло «роз'їжджене толеранційністю поганство» (Донцов, Вибрані 3: 261).

Занурення в історичне минуле характерне і для публіциста, бо дозволяє усвідомити політику 1917 року, коли «верхи всіляко гамували народну енергію» і не давали розв'язати проблему Київ-Москва, а поразка національно-визвольних змагань (1918-1921р.) стала тим переломним моментом історії, коли національна ідея почала наповнюватися виразним змістом та отримала можливі шляхи вирішення. Як унаочнення він цитує поетку-пророчицю, показує iї несприйняття дійсности, аналізує повторюваність невдач української боротьби, тому персономен Леся Українка у його публіцистиці відтворює спіралеподібність ситуації, що триває на українських землях.

Знаковим для письменниці $\epsilon$ приховування під чужою одежею українських реалій, що можна пояснювати по-різному. Доба Руїни, поразка Хмельниччини - це все вплинуло на те, що Леся Українка шукає героїв в історичному ракурсі. 3 іншого погляду, давалися взнаки її гени, бо батьківський родовід сягав Босніїі та був знаний на тих землях у XIV-XV столітті. Відважність грецького роду за материною лінією має протяжність 3 часів Хмельниччини, коли існувала потреба в драгоманах (себто перекладачах). Отож природніми для письменниці були героїчні шляхи різних народів, а численні переклади та знання европейських мов уможливили звуалювати український дух через екзотичні персонажі. Зрештою, античний код сповна міг відтворити українські національно- 
політичні проблеми, можливо, тому i спричинив вплив на творчу лабораторію Лесі Українки, яку Д. Донцов пояснив «ще й стидливістю хисту поетки, що уникала називати речі їх іменем, шукаючи для виявлення своїх ідей - чужих постатей, чужі убрання, проміння чужого, яснішого сонця» (Донцов, Вибрані 8: 30).

Чинником для утвердження в творах поетки національних ідей $є$ не лише традиції роду, а й громадського-політичне життя Галичини. Тодішньою політичною реакцією на події в країні $\epsilon$ створення ЛНВ, у результаті діяльности якого відбувається процес становлення політичної нації. «Наша література в частині творів потребує політологічної думки, відкидати її - означає збіднювати прочитання художнього тексту» (Токмань 9). Отож вагомою є тяглість поколінь, яку ввібрали до своєї програми життя ідеї, започатковані ЛНВ. Цікаво, що на запросини І. Франка у «Літературно-науковому вістнику» виходять численні переклади та твори Лесі Українки. Згодом відновлений ЛНВ, який за часів Франка друкував поетку, став політичною трибуною Д. Донцова. Зазначимо, що I. Франка Леся вважає своїм вчителем, а Д.Донцов своєю вчителькою вважає Лесю Українку. Прикметно, що саме I. Франко бачить в творчості письменниці політичну основу, говорить, що її твори привели «до широкої ідейності і могутнього пристрасного вогню» (Франко 255). Отож заграва та пророчість стали ознакою мовотворчости Лесі Українки (Микитюк).

Однозначно неприйнятним для мислителя та поетки є московська неволя. Проблему українськости Леся Українка яскраво виписала в драмі «Бояриня», що демонструє залежність України від Московї. Також чи не найбільше Д. Донцов говорить про причини національних невдач, якими $€$ зневіра у власних силах, безхарактерність, відсутність української провідної верстви. «Бояриня» показала русофільські настрої, спростувала ідею повірити в доброго царя, відкинула драгоманівські думки про можливу свободу начебто під протекторатом Москви, розкрила агресивність московських звичаїв та московський менталітет. На жаль, методика винищення української ідеї згодом буде вдосконалюватися в численній публіцистиці совєтських часів, а твори Д. Донцова з його ідеєю боротьби вийдуть на українських овид аж за часів самостійної України.

\section{3. Категорія свій у Лесі Українки та Д. Донцова}

Стилістично актуалізованим у поетки-пророчиці $\epsilon$ поняття свій. Знаючи вагу чужого (бо величезна перекладацька праця, задум створити «Європейську бібліотеку» українською мовою), Леся Українка неухильно творила своє. Любов до рідного краю, закладена 3 дитинства, українськоцентрична освіта від мами, потужна самоосвіта - усе це створило чин праці.

Ідеалом для Д.Донцова $є$ світогляд Лесі, бо «для неї були важні тільки такі категорії: «свій народ, чужий народ, своя держава, чужа держава, свої боги, чужі боги» (Донцов, Вибрані 8: 32). Така сама позиція мислителя, який унаочнює ідеологічні основи української держави, 
першочерговим для якої є покладатися лише на власні сили, а не на чужинців. Категорію свій Д.Донцов виразно проартикулював у творі «Націоналізм»: «Кожна нація має свій власний закон, свою власну правду й повинна лише їм коритися» (221).

Привертає увагу, що в драмі Лесі Українки «На руїнах» категорія свій чужий невідступно породжує категорію воля - рабство. На питання «Хто раб?» Пророчиця відповідає: «Тільки той, хто самохіть несе ярмо неволі». Аналогічно в Д. Донцова: «Путь до свободи веде не через буденну працю, а через жорстоку боротьбу, що треба бути самому сильнішим за хижака, шляхетним і зубатим псом сторожовим» (Донцов, Вибрані 9: 333).

Отже, категорія свій є символом удержавленням в творах Д. Донцова та має численне вираження в поняттях свій край, свій рідний край, свій шлях, свій національний світогляд, свій національний характер, свій обов'язок, свій народ, свій натхненний голос, сій сенс, свій хліб, свій власний досвід, свій прапор, свій ідеал, свій колективний ідеал, свій власний закон, своя власна правда, свій зміст, свій світ, свій націоналізм, свій твір. Матеріал роботи переконує, що мовотворчість Д. Донцова та Лесі Українки увічнена та наповнена лексемою свій, що характеризує та віддзеркалює їхні цінності.

\section{4. Біблійні елементи в творчості Леся Українки та Д. Донцова}

Стилістично маркованими є біблійні елементи в творах Д. Донцова, які підсилено персономеном Леся Українка. Численними прикладами мислитель переконує, що Святе письмо знає лише слово «Так» і «Ні», а ті, що не вміють послуговуватися такими словами - це «люди “холодного розуму" - це люди без віри, без любови. Це люди вічно хиткі» (Донцов, Вибрані 9: 260-261) та вважає, що світова історія викине таких на смітник. Однозначними щодо біблійних постулатів $\epsilon$ Леся Українка, яка, як i Д. Донцов, дотримується моралі, що «не літеплі творять тривале й велике на землі» (Донцов, Вибрані 10: 220). Отож тільки сильні особистості здатні змінити світ, а серединний шлях руйнує світосприймання та світовідчуття. Висновок мислителя очевидний: для того, щоб бути вільним, «не кидаймося справа наліво і зліва направо! Хай наше слово буде “Так” або “Ні"!» (Донцов, Хрестом 266).

\section{5. Сила духу в працях Лесі Українки}

Д. Донцов переконаний: Леся Українка «натхнула нас новим, не плебейським ідеалом краси життя, <...> відкрила видиво нового щастя пориву і бунту» (Донцов, Вибрані 8: 351). Сила духу у виборі позицї $\epsilon$ ідейним первнем у творах поетки. Мислитель пояснює, як Леся Українка (як небагато письменників) задихалася «в атмосфері літератури народжуваного хама, соціяльнореволюційної фанфаронади, благодушного провінціоналізму, селянського етнографізму, порнографії» (Донцов, Вибрані 5: 97). Письменниця постійно у віршах, поемах торкається політичного становища своєї країни, тому у їі творчості мислитель бачить, якою національною гідністю сповнені слова про українську літературу, 
пристрасно розкриває ії «таємничу лабораторію душі» (Донцов, Вибрані 8: 43), показує, як вона думала барвами, контрастами світла й тіні, які відтворювали моменти руху. До речі, проти спотворення постаті Лесі Українки боровся також Р. Бжеський, який не сприймав соціалістичних трактувань їі творів (Гладкович 29). Отож філософія Лесі Українки як боротьба за душу людини яскраво виражена в націоналістичному контексті.

Висновки та перспективи досліджень. Спортретована Леся Українка в Д. Донцова $є$ стилістичним маркером його публіцистики. Матеріал роботи стверджує, що позитивна конотація персономена Леся Українка присутня у всіх ідеологічних висловах мислителя, він захоплюється іiї політичними оцінками дійсности, висновками, які передували суспільній думці.

Тематика Донцовських текстів крізь подачу персономена Леся Українка є втіленням духових настанов, національних ідеалів, непохитної віри та непогамовної сили для утвердження української держави.

У статті доведено, що програма боротьби $є$ спільною для Лесі Українки та Д. Донцова. Поетка приховує під чужою одежею події далекого минулого, щоб увиразнити українську свободолюбність. Д. Донцов також показує невдачі 1918-1921 років, бо українська ідея крізь віддаль часу стає чітко сформованою.

Важливо, що лексема свій у «великої бунтарки» базована на поняттях свій народ, своя держава. Д. Донцов у творах «Націоналізм», «Дух нашої давнини», як і поетка, наголошує на позиції свій шлях, свій національний характер, свій обов'язок, свій хліб, свій прапор, свій ідеал - себто формує ідеологеми, що заклали основи українського світогляду.

Ілюстрацію біблійних елементів у драмах Лесі Українки обумовила Євангельська правда про опозитивні слова «Так» і «Ні», бо серединний шлях - це шлях хиткий. Леся Українка проти літеплих, які не здатні на великі вчинки. Ця думка поетки підсилена словами Д. Донцова, який теж за чіткість та однозначність у виборі позиції, за сильні особистості, які бачать шляхи утвердження своєї правди.

Знаково, що Леся Українка силою духу та письма протистояла провінціалізмові в літературі й утверджувала національну гідність, яку Д. Донцов у її творах прочитав як рух, контраст, барви.

На завершення розвідки хочу висвітлити факт сьогодення: до 150літття від дня народження Лесі Українки дала завдання студентами написати можливі асоціації до постаті поетки. Отримані результати приголомшили, бо це були лексеми хвороба, біль, ревматизм, лікування, страждання..., тобто всі лексеми мали домінантною ідею хвороби. Відтак хочеться зрозуміти, хто виховав покоління, котре не вміє бачити «яскравого смолоскипу нашого минулого» (Д. Донцов). Отож, аби змінити цей ланцюг, варто читати Д. Донцова, який у мовно-політичному портреті Лесі Українки утверджує ідеал сили, боротьби, нескорености, величі та гордости. 
Перспективою досліджень $\epsilon$ аналіз мовних портретів класиків української літератури та культури за творами Д. Донцова.

\section{Список використаних джерел}

Донцов, Дмитро. Вибрані твори, упорядкування, післямова, коментарі О. Баган. В 10 т. Дрогобич: Відродження, 2011-2016.

Донцов, Дмитро. Дух нашої давнини. Львів-Київ: Накладом Юрія Криворучка, 2011.

Донцов, Дмитро. Націоналізм. Вінниця, 2006.

Донцов, Дмитро. Хрестом і мечем. Тернопіль: Рада, 2010.

\section{Sources}

Dontsov, Dmytro. Vybrani tvory, edited by O. Bahan. 10 vols. Drohobych: Vidrodzhennia, 2011-2016.

Dontsov, Dmytro. Dukh nashoi davnyny. Lviv-Kyiv: Nakladom Yuriia Kryvoruchka, 2011.

Dontsov, Dmytro. Natsionalizm. Vinnytsia, 2006.

Dontsov, Dmytro. Khrestom i mechem. Ternopil: Rada, 2010.

\section{Список використаної літератури}

Баган, Олег. «Ідеологія сили і наступу (Дмитро Донцов і світоглядні параметри вольового націоналізму)». Донцов, Дмитро. Вибрані твори, упорядкування, післямова, коментарі О. Баган. В 10 т. Т. 7. Ідеологічна та історіософська есеїстика (1923-1939 рр.). Дрогобич: Відродження, 2014, с. 5-18.

Баган, Олег. Поміж містикою і політикою (Дмитро Донцов на тлі української політичної історії першої половини XX ст.). Київ, 2008.

Богдан, Світлана. «...Мені треба одежу, варту мого писательського стану» (Одяг у контексті епістолярного автопортрета Лесі Українки). Дивослово. № 10, 2016, c. 35-44.

Богдан, Світлана. Епістолярний ідіолект Лесі Українки в інтер'єрі родинної комунікації: уліта. Лінгвостилістичні студіï, вип. 13, 2020, с. 16-34. https://doi.org/10.29038/2413-0923-2020-13-16-34.

Гладкович, Мар'яна. Постать Лесі Українки в рецепції Романа Бжеського. Ідеологиня національної аристократії (на пошану 150-річчя від дня народження Лесі Українки): збірник наукових праць, наук. ред. Тетяна Єщенко. Львів: Друкарня Львівського національного медичного університету імені Данила Галицького, 2021, с. 25-30.

Дашкевич, Ярослав. Дмитро Донцов і боротьба довкола його спадщини. Постаті: Нариси про діячів історії, політики, культури, упорядники М. Капраль, Г. Сварник, І. Скочиляс. Львів: Піраміда, 2007, с. 525-34.

Денисюк, Іван, Скрипка Тамара. Дворянське гніздо Косачів. Львів: Академічний експрес, 1999.

Забужко, Оксана. Notre Dame d’Ukraine: Українка в конфлікті міфологій. Київ: Факт, 2007.

Ідеологиня національної аристократії (на пошану 150-річчя від дня народження Лесі Українки): збірник наукових пращь, наук. ред. Тетяна Єщенко. Львів: Друкарня Львівського національного медичного університету імені Данила Галицького, 2021.

Квіт, Сергій. Дмитро Донцов: ідеологічний портрет. Львів: Галицька видавнича спілка, 2013.

Маланюк, Євген. До роковин Лесі Українки. Книга спостережень, 1962. URL: http://ukrlife.org/main/evshan/malaniuk3.htm.

Мацько, Любов, і Сидоренко, Олеся. «Мовотворчість Лесі Українки». Дивослово, № 3, 2002, с. $14-6$. 
Микитюк, Оксана. «Незламність духу, або Леся Українка в трактуванні Дмитра Донцова». Ідеологиня національної аристократії (на пошану 150-річчя від дня народження Лесі Українки): збірник наукових праць, наук. ред. Тетяна Єщенко. Львів: Друкарня Львівського національного медичного університету імені Данила Галицького, 2021, с. 355-61.

Міщенко, Леоніла. Леся Українка. Київ: Наукова думка, 1986.

Супрун, Людмила. «Кваліфікатив “національний” у контексті вісниківської публіцистики Д. Донцова». Науковий вісник Міжнародного гуманітарного університету. Серія: Філологія, № 5, 2015, с. 158-61.

Токмань, Ганна. «Україна як простір мови і політичного виховання». Дивослово, № 3, 2006, с. 4-9.

Трач, Людмила. «Західноукраїнські лексичні елементи в мові Лесі Українки». Урок української, № 10, 2006, с. 29-34.

Фаріон, Ірина. «Леся Українка і мовне питання». Ідеологиня національної аристократії (на пошану 150-річчя від дня народження Лесі Українки): збірник наукових праць, наук. ред. Тетяна Єщенко. Львів: Друкарня Львівського національного медичного університету імені Данила Галицького, 2021, с. 209-15.

Франко, Іван. «Леся Українка». Франко, Іван. Зібрання творів. В 50 т. Т. 31. Київ: Наукова думка, 1981, с. 254-74.

Чугуєнко, Михайло. Формування та розвиток ідеологї Дмитра Донцова. Автореф. дис. ... канд. філософ. наук: 09.00.12. Харків, 1998.

Шліхта, Ірина. Дмитро Донцов як ідеолог $i$ теоретик украйнського націоналізму. Автореф. дис. .... канд. істор. наук: 07.00.01. Київ, 2005.

Erlacher, Trevor. "The birth of Ukrainian active nationalism: Dmytro Dontsov and heterodox Marxism before world war I, 1883-1914". Modern Intellectual History, no. 11(3), 2014, pp. 519-48.

\section{References}

Bahan, Oleh. "Ideolohiia syly i nastupu (Dmytro Dontsov i svitohliadni parametry volovoho natsionalizmu)". Dontsov, Dmytro. Vybrani tvory, edited by 0. Bahan. 10 vols. Vol. 7: Ideolohichna ta istoriosofska eseistyka (1923-1939). Drohobych: Vidrodzhennia, 2014, pp. 5-18.

Bahan, Oleh. Pomizh mistykoiu i politykoiu (Dmytro Dontsov na tli ukrainskoi politychnoi istorii pershoi polovyny XX st.). Kyiv, 2008.

Bohdan, Svitlana. ““...Meni treba odezhu, vartu moho pysatelskoho stanu” (Odiah u konteksti epistoliarnoho avtoportreta Lesi Ukrainky)". Dyvoslovo, no. 10, 2016, pp. 35-44.

Bohdan, Svitlana. "Epistoliarnyi idiolekt Lesi Ukrainky v interieri rodynnoi komunikatsii: ulita”. Linhvostylistychni studii, iss. 13, 2020, pp. 16-34. https://doi.org/10.29038/2413-0923-2020-13-16-34.

Hladkovych, Mariana. "Postat Lesi Ukrainky v retseptsii Romana Bzheskoho". Ideolohynia natsionalnoi arystokratii (na poshanu 150-richchia vid dnia narodzhennia Lesi Ukrainky), edited by Tetiana Yeshchenko. Lviv: Drukarnia Lvivskoho natsionalnoho medychnoho universytetu imeni Danyla Halytskoho, 2021, pp. 25-30.

Dashkevych, Yaroslav. "Dmytro Dontsov i borotba dovkola yoho spadshchyny". Postati: Narysy pro diiachiv istorii, polityky, kultury, edited by M. Kapral, H. Svarnyk, I. Skochylias. Lviv: Piramida, 2007, pp. 525-34.

Denysiuk, Ivan, Skrypka, Tamara. Dvorianske hnizdo Kosachiv. Lviv: Akademichnyi ekspres, 1999.

Zabuzhko, Oksana. Notre Dame d'Ukraine: Ukrayinka in the Conflict of Mythologies. Kyiv: Fakt, 2007. 
Ideolohynia natsionalnoi arystokratii (na poshanu 150-richchia vid dnia narodzhennia Lesi Ukrainky), edited by Tetiana Yeshchenko. Lviv: Drukarnia Lvivskoho natsionalnoho medychnoho universytetu imeni Danyla Halytskoho, 2021.

Kvit, Serhii. Dmytro Dontsov: ideolohichnyi portret. Lviv: Halytska vydavnycha spilka, 2013.

Malaniuk, Yevhen. "Do rokovyn Lesi Ukrainky". Knyha sposterezhen, 1962. ukrlife.org/main/evshan/malaniuk3.htm.

Matsko, Liubov, Sydorenko, Olesia. "Movotvorchist Lesi Ukrainky". Dyvoslovo, no. 3, 2002, pp. 14-16.

Mykytiuk, Oksana. "Nezlamnist dukhu, abo Lesia Ukrainka v traktuvanni Dmytra Dontsova". Ideolohynia natsionalnoi arystokratii (na poshanu 150-richchia vid dnia narodzhennia Lesi Ukrainky), edited by Tetiana Yeshchenko. Lviv: Drukarnia Lvivskoho natsionalnoho medychnoho universytetu imeni Danyla Halytskoho, 2021, pp. 355-61.

Mishchenko, Leonila. Lesia Ukrainka. Kyiv: Naukova dumka, 1986.

Suprun, Liudmyla. "Kvalifikatyv "natsionalnyi" u konteksti visnykivskoi publitsystyky D. Dontsova". Naukovyi visnyk Mizhnarodnoho humanitarnoho universytetu. Seriia: Filolohiia, no. 5, 2015, pp. 158-61.

Tokman, Hanna. "Ukraina yak prostir movy i politychnoho vykhovannia". Dyvoslovo, no. 3, 2006, pp. 4-9.

Trach, Liudmyla. "Zakhidnoukrainski leksychni elementy v movi Lesi Ukrainky". Urok Ukrainskoi, no. 10, 2006, pp. 29-34.

Farion, Iryna. "Lesia Ukrainka i movne pytannia". Ideolohynia natsionalnoi arystokratii (na poshanu 150-richchia vid dnia narodzhennia Lesi Ukrainky): edited by Tetiana Yeshchenko. Lviv: Drukarnia Lvivskoho natsionalnoho medychnoho universytetu imeni Danyla Halytskoho, 2021, pp. 209-15.

Franko, Ivan. "Lesia Ukrainka”. Franko, Ivan. Zibrannia tvoriv. 50 vols. Vol. 31. Kyiv: Naukova dumka, 1981, pp. 254-74.

Chuhuienko, Mykhailo. Formuvannia ta rozvytok ideolohii Dmytra Dontsova. PhD Thesis Abstract. Kharkiv, 1998.

Shlikhta, Iryna. Dmytro Dontsov yak ideoloh i teoretyk ukrainskoho natsionalizmu. PhD Thesis Abstract. Kyiv, 2005.

Erlacher, Trevor. "The birth of Ukrainian active nationalism: Dmytro Dontsov and heterodox Marxism before world war I, 1883-1914". Modern Intellectual History, no. 11(3), 2014, pp. 519-48. 